\title{
Mini-report on the association between obesity and acute myocardial infarction in Japanese
}

\author{
Eiji Oda* \\ Medical Check-up Center, Tachikawa General Hospital, Asahioka 1-24, Nagaoka, Niigata, 940-8621 Japan
}

Obesity is a marker of the clustering of metabolic risk factors for coronary heart disease (CHD) [1,2] and obesity itself is also an independent risk factor of $\mathrm{CHD}$ among white populations [3-6]. Obesity is not prevalent in Japan and the prevalence of CHD in Japan has been reported to be the lowest among developed countries $[7,8]$. The low prevalence of obesity and CHD in Japan may partly result from the low-fat vegetable- and fish-rich Japanese diet $[9,10]$. There have been conflicting data regarding the relationship between obesity and $\mathrm{CHD}$ in Japan [11-18]. Some studies have suggested a significant association between obesity and CHD in Japanese [11,13] but others have found opposite results $[12,15,17,18]$. A case-control study suggested that obesity is independently associated with acute myocardial infarction (AMI) in young and middle-aged men, but not in women and older men [16]. The age- and sex-related differences in the association between risk factors of CHD and abdominal obesity might contribute, at least in part, to these conflicting data in Japan [19]. So, we investigated the ageand sex-related association between obesity and AMI after controlling for diabetes, hypertension, hypercholesterolemia, and smoking in ageand sex-matched case-control samples in Japan [20].

This observational case-control study was based on the data of 1,199 AMI patients who were admitted to our Cardiovascular Center within 10 days from symptom onset and 4,056 apparently healthy controls. The exclusion criteria were a history of prior myocardial infarction, non-Japanese ethnicity, age $\geq 80$ years and the lack of body weight and height information. Body mass index (BMI) was calculated as body weight $(\mathrm{kg})$ divided by square of height $(\mathrm{m})$ and obesity was defined as $\mathrm{BMI} \geq 25 \mathrm{~kg} / \mathrm{m}^{2}$ [20]. Diabetes was diagnosed by pre-admission information or fasting glucose $\geq 7.0 \mathrm{mmol} / \mathrm{L}$ and/or hemoglobin A1c $\geq 6.5 \%$ (NGSP). Hypertension was diagnosed by pre-admission information or systolic blood pressure $\geq 140 \mathrm{mmHg}$ and/or diastolic blood pressure $\geq 90 \mathrm{mmHg}$ in later stable hospital days after admission. Hypercholesterolemia was diagnosed by pre-admission information or total cholesterol $\geq 5.7 \mathrm{mmol} / \mathrm{L}$ and/or LDL cholesterol $\geq 3.6 \mathrm{mmol} / \mathrm{L}$.

The analysis was performed in age- and sex-matched samples of 621 case-control pairs and, in crude samples aged 40-79 years, were divided into 10-year age groups. Prevalence of obesity, diabetes, current smoking, hypertension, and hypercholesterolemia were compared between cases and controls and a multivariable odds ratio (OR) of AMI was calculated for each risk factor in various age groups.

The OR (95\% confidence interval (CI)) of AMI for obesity was 1.63 $(1.23-2.17) p<0.001$ in men younger than 80 years and $2.65(1.41-5.00)$ $p=0.003$ in women younger than 80 years, $2.23(1.46-3.41) p<0.001$ in men aged 59 years or younger, $1.34(0.90-2.01) p=0.15$ in men aged $60-79$ years, $2.98(1.56-5.71) p=0.001$ in women aged $60-79$ years using paired samples. The OR (95\% CI) of AMI for obesity was 4.92 (2.539.58) $p<0.001$ in men aged $40-49$ years, $1.54(1.07-2.21) p=0.02$ in men aged 50-59 years, $1.07(0.69-1.66) p=0.77$ in men aged $60-69$ years, 2.24 $(1.20-4.20) p=0.01$ in men aged $70-79$ years, $2.48(1.12-5.48) p=0.02$ in women aged $60-69$ years, and $3.05(1.46-6.37) p=0.003$ in women aged 70-79 years using crude samples.

The above results demonstrated that obesity was independently associated with AMI in men aged 59 years or younger, men aged 70-79 years, and women aged 79 years or younger but not in men aged 6069 years. Diabetes and current smoking were strongly associated with AMI in both men and women in this Japanese population. Thus, the association between obesity and AMI was age- and gender-dependent in a Japanese population. Weight reduction should be recommended to obese individuals, especially those with metabolic syndrome. However, it should be carefully considered for elderly evaluating the risks and benefits weight reduction.

\section{References}

1. Klein S, Allison DB, Heymsfield SB, Kelley DE, Leibel RL, et al. (2007) Wais circumference and cardiometabolic risk: a consensus statement from Shaping America's Health: Association for Weight Management and Obesity Prevention; NAASO, The Obesity Society; the American Society for Nutrition; and the American Diabetes Association. Am J Clin Nutr 85: 1197-1202. [Crossref]

2. Oda E, Kawai R (2010) Comparison among body mass index (BMI), waist circumference (WC), and percent body fat $(\% \mathrm{BF})$ as anthropometric markers for the clustering of metabolic risk factors in Japanese. Intern Med 49: 1477-1482. [Crossref]

3. Jousilahti P, Tuomilehto J, Vartiainen E, Pekkanen J, Puska P (1996) Body weight, cardiovascular risk factors, and coronary mortality: 15-year follow-up of middle-aged men and women in eastern Finland. Circulation 93: 1372- 1379. [Crossref]

4. Calle EE, Thun MJ, Petrelli JM, Rodriguez C, Heath CW Jr (1999) Body mass index and mortality in a prospective cohort of U.S. adults. N Engl J Med 341: 1097-1105. [Crossref]

5. van Dis I, Kromhout D, Geleijnse JM, Boer JM, Verschuren WM (2009) Body mass index and waist circumference predict both 10 -year nonfatal and fatal cardiovascular disease risk: study conducted in 20,000 Dutch men and women aged 20-65 years. Eur J Cardiovasc Prev Rehabil 16: 729-734. [Crossref]

6. Pischon T, Boeing H, Hoffmann K, Bergmann M, Schulze MB, et al. (2008) Genera and abdominal adiposity and risk of death in Europe. New Engl J Med 359: 2105-2120. [Crossref]

7. Yoshida M, Kita Y, Nakamura Y, Nozaki A, Okayama A, et al. (2005) Incidence of acute myocardial infarction in Takashima, Shiga, Japan. Circ J 69: 404-408. [Crossref]

8. Nishigaki K, Yamazaki T, Fukunishi M, Tanihata S, Fujiwara H, et al. (2004) Assessment of acute myocardial infarction in Japan by Japanese coronary intervention study (JCIS) group. Circ J 68: 515-519. [Crossref]

${ }^{\star}$ Correspondence to: Eiji Oda, Medical Check-up Center, Tachikawa General Hospital, Asahioka 1-24, Nagaoka, Niigata, 940-8621 Japan, E-mail: ijie@venus. sannet.ne.jp

Received: May 07, 2018; Accepted: May 18, 2018; Published: May 25, 2018 
9. Oda E, Hatada K, Katoh K, Kodama M, Nakamura Y, et al. (2005) A case-control pilot study on $\mathrm{n}-3$ polyunsaturated fatty acid as a negative risk factor for myocardial infarction. Int Heart J 46: 583-591. [Crossref]

10. Iso H, Kobayashi M, Ishihara J, Sasaki S, Okada K, et al. (2006) Intake of Fish and n3 Fatty Acids and Risk of Coronary Heart Disease Among Japanese: The Japan Public Health Center-Based (JPHC) Study Cohort I. Circulation 113: 195-202. [Crossref]

11. Takahashi T, Chikamori T, Yonezawa Y, Sugimoto K, Yamada M, et al. (1997) Prognostic value of serum cholesterol level in Japanese patients with coronary artery disease. Jpn Circ J 61: 139-144. [Crossref]

12. Miyake Y (2000) Risk factors for non-fatal acute myocardial infarction in middle-aged and older Japanese. Jpn Circ J 64: 103-109. [Crossref]

13. Nakamura T, Tsubono Y, Kameda-Takemura K, Funahashi T, Yamashita S, et al. (2001) Magnitude of sustained multiple risk factors for ischemic heart disease in Japanese employees: A case-control study. Jpn Circ J 65: 11-17. [Crossref]

14. Washio M, Hayashi R (2004) Past history of obesity (overweight by WHO criteria) is associated with an increased risk of nonfatal acute myocardial infarction: A casecontrol study in Japan. Circ J 68: 41-46. [Crossref]
15. Kawano H, Soejima H, Kojima S, Kitagawa A, Ogawa H (2006) Sex differences of risk factors for acute myocardial infarction in Japanese patients. Circ J 70: 513-517. [Crossref]

16. Shiraishi J, Kohno Y, Sawada T, Nishizawa S, Arihara M, et al. (2006) Relation of obesity to acute myocardial infarction in Japanese patients. Circ J 70: 1525-1530. [Crossref]

17. Kadota A, Hozawa A, Okamura T, Kadowaki T, Nakmaura K, et al. (2007) Relationship Between Metabolic Risk Factor Clustering and Cardiovascular Mortality Stratified by High Blood Glucose and Obesity: NIPPON DATA90, 1990-2000. Diabetes Care 30: 1533-1538. [Crossref]

18. Saito Y, Kita T, Mabuchi H, Matsuzaki M, Matsuzawa Y, et al. (2010) Obesity as a risk factor for coronary events in Japanese patients with hypercholesterolemia on low-dose simvastatin therapy. J Atheroscler Thromb 17: 270-277. [Crossref]

19. Oda E, Kawai R (2009) Age- and gender-related differences in correlations between abdominal obesity and obesity-related metabolic risk factors in Japanese. Intern Med 48: 497-502. [Crossref]

20. Oda E, Goto M, Matsushita H, Takarada K, Tomita M, et al. (2013) The association between obesity and acute myocardial infarction is age- and gender-dependent in a Japanese population. Heart Vessels 28: 551-558. [Crossref]

Copyright: (2018 Oda E. This is an open-access article distributed under the terms of the Creative Commons Attribution License, which permits unrestricted use, distribution, and reproduction in any medium, provided the original author and source are credited. 